\title{
The challenges of social investment through the lens of microfinance ${ }^{1}$
}

\author{
Jonathan Morduch and Timothy Ogden
}

The rhetoric of social investment is grand and clear, and the basic vision is simple: to support a new sort of capitalist endeavor driven by pursuit of social progress rather than just pursuit of profit. Yet the reality can be messy. How could it not be? Modern history has been shaped by the tensions between unbridled capitalism and struggles for social and economic justice. So it is not surprising that in the same 12 months that publishers release hope-filled books on social investment like A World of Three Zeros: The New Economics of Zero Poverty, Zero Unemployment and Zero Net Carbon Emissions (Yunus 2017), other publishers release bubblebursting exposés like Winners Take All: The Elite Charade of Changing the World (Giridharadas 2018).

Against the backdrop of these tensions, the world of social investment somehow embraces both market denialism and market fundamentalism. It depends on large subsidies while deploying anti-subsidy rhetoric. Definitions and practice have become so squishy that the coiner of one of the seminal terms of social investment, the "triple-bottom line", recently suggested "recalling" the term because it is now essentially meaningless (Elkington 2018).

Despite the conundrums and contradictions, the critique of raw capitalism embedded in social investment remains compelling, and real progress has been made in turning ideas into actions, extending far beyond pilot programs and experimental trials. Large, well-funded organizations, like the Rockefeller Foundation and Skoll Foundation, have worked for years to build and establish the sector. Billions of dollars have poured in, large conferences are held across the globe, and university curricula have been populated (including a new program on Social Impact, Innovation, and Investment at our own institution, the Wagner Graduate School at New York University).

In this chapter, we set out fundamental questions about microfinance as seen through the lens of social business and social investment. We also do the reverse, asking questions about social business and social investment through the lens of

\footnotetext{
1 This chapter draws on ideas and evidence developed over time and in collaboration with co-authors and other interlocutors including Beatriz Armendáriz, Lucy Bernholz, Asli Demirgüç-Kunt, Jonathan Conning, Robert Cull, Eric Rice, Tony Sheldon, and Scott Taitel. We also appreciate comments (and conversations over the years) with the book's editors. None are responsible for the views or any errors here.
} 
microfinance. The aim is to focus on key tensions and possibilities, with an eye toward creating a research agenda and with an emphasis on tensions between financial goals and social impacts. ${ }^{2}$ We are not advocates for social business and social investment, nor are we cynics. We sit in an academic institution, and our aim is to push for clearer thinking and better use of evidence. To put our cards on the table, we are suspicious of claims that ignore the value of markets and their contribution to improving lives and raising living standards; we are even more suspicious of claims that market-oriented interventions are capable of solving large social problems on their own.

In many ways, microfinance has been a laboratory for social investment. Indeed, because of its early role in putting social investment ideas into practice, microfinance provides a chance to understand the possibilities, limits, and conundrums of social business and social investment. ${ }^{3}$ The idea of microfinance is to create financial services in communities that otherwise would lack efficient, reliable places to borrow, save, and insure. The aim is to achieve social goals through business mechanisms, to expand access in areas served badly by other businesses because the customers are seen as being undesirable: too poor, too costly to serve, too risky; but sometimes also, the wrong gender, the wrong nationality, the wrong ethnicity. Microfinance entered the market with a new mechanism for delivering credit that did not require collateral, thus providing the possibility of serving the poor and assetless. Along with that step came a new business model-or, perhaps more to the point, a new way of thinking about business models, where investors have social goals as well.

While microfinance investors and practitioners may have social goals, customers are expected to pay their share too: the business model relies on charging customers for goods and services. In the case of microfinance, the prices mostly take the form of interest rates, but in other cases the prices may be collected as school fees, fee-for-service healthcare, or "pay-go" models for electricity generated from local solar panels. The aim is to create a business ethos within organizations and to be able to expand without reliance on philanthropic funding. Still, there is often an element of subsidy involved. Cull et al. (2018) found, for example, that in a sample of 1,024 microfinance institutions, just 36 percent were fully profitable when weighted by borrowers and just 18 percent when weighted by assets. Most institutions relied on subsidy, usually in the form of cheap capital from social investors. Moreover, the subsidy received by institutions was sometimes large and often long-lasting.

The dependence on subsidy has not prevented microfinance from becoming a global phenomenon. In fact, subsidy has propelled the sector. Microfinance has now reached global scale, built a complete infrastructure (for example capital and

\footnotetext{
2 This is not a comprehensive research list. For example, we do not discuss questions around how to optimally invest for social impact. By taking an equity stake? Lending? Offering to a first-loss guarantee on debt? Making direct grants? Instead our focus is largely on the balance between financial and social impacts.

3 Examples of social business arose much before microfinance and ideas developed along parallel paths. Other related books include Simon (2017) and Bugg-Levine and Emerson (2011).
} 
information intermediaries), and tapped into commercial capital on multiple continents (Cull et al. 2009; Beck 2015). Indeed, it is one of the few social sectors to produce enough profit to generate heated controversy over the financial returns to social investment (Rosenberg 2007 and 2009; Yunus 2011).

The core questions raised below are:

1. What is social business and social investment? How do these concepts differ from "regular" business and investment?

2. How do user fees (including prices and interest rates) help and hurt customers and businesses?

3. How worrisome is mission drift, and why does it happen?

4. What is the role of subsidy?

5. How should social returns be measured?

\section{What is social business and social investment?}

There is no satisfactory definition of social business and social investment, and a research agenda could profitably start with definitions.

We'll start with social investment and what it is not. Social investment is often conflated with "socially-responsible investment." The latter refers to investment in businesses that take steps to avoid doing harm; it is a strategy that screens out investments in, for instance, tobacco companies and major polluters. Specifically, socially responsible investors often focus on Environmental, Social and Governance (ESG) criteria. The environmental criteria relate to efforts like combatting climate change, or at least not worsening it, and adopting environmentally sustainable practices. The social criteria similarly focus on how businesses treat their employees, customers, and members of the community. And the governance criteria focus on issues like conflict of interest, internal controls, shareholder rights, and equity in pay scales. ${ }^{4}$ (For more, see Gold 2017.)

The unifying theme of socially-responsible investment is that businesses receiving investments should not be unethical, and the focus is on publicly traded bonds and equity (Spiess-Knafl and Scheck 2017). In contrast, Muhammad Yunus (2010) and many others see social businesses as organizations that actively pursue good. Social investment, in parallel, is seen as investment that supports social business, most often through private equity and private debt. ${ }^{5}$

\footnotetext{
4 As Sindreau and Kent (2018) write, the devil is in the definitions. "A [Wall Street] Journal analysis of four leading ESG ratings providers found that they come to completely different conclusions about what makes a company a 'sustainable' investment." Moreover, Vanguard, a leading mutual fund company, says it "leaves out companies with 'the most severe' environmental, social and governance issues, but outright exclusion from the fund requires violating United Nations Global Compact principles-such as engaging in slavery_or producing land mines and cluster bombs."

5 The Global Impact Investing Network (GIIN), an organization dedicated to promoting social investment, defines social
} 
Still, even that concept leaves a broad spectrum of possibility. For example, consider the British-Dutch global conglomerate Unilever, seller of toiletries, soaps, food, and drink, with a global presence and a market value of \$168 billion in late 2018. Is it a social business, and is buying shares of Unilever a social investment? Unilever makes the world better off by manufacturing and distributing inexpensive soap, toothpaste, and so on. The company touts their "purpose-led brands" and their commitment to ESG criteria. They have committed that "By 2020 we will help more than a billion people take action to improve their health and well-being." 6 In fact, the Unilever website describes their brands as "on a journey to reducing their environmental footprint and increasing their positive social impact." it matter that Unilever operates (as far as we can see) with pure profit motives and can obtain capital in standard ways through capital markets and other financial institutions?

A different angle considers elements that are special to the investment practice. To parallel the definition of a social business, a social investment must actively pursue a social good. This is an important idea because so much of the rhetoric around social investment, especially around ideas like "double" and even "triple" bottom lines, plays down the existence of trade-offs. But dig deeper, and there is usually a financial trade-off. Some may argue that social investment does not need to (or should not) entail financial trade-offs, implicit or explicit, that multiple bottom lines are possible without compromise on any dimension. But, in our view, the position is untenable. If there were no financial trade-offs, there would be no need for social investment; other (non-social) investors would happily fund social businesses, just as they seem to happily fund Unilever.

How can investors actively pursue social good? A common claim is that social investors must be more patient-rather than chasing short-term financial gains, say, they are willing to forego them, and perhaps even risk bearing substantial losses, in order to allow a social businesses to grow and take risks (see the discussion in Taitel 2018). ${ }^{8}$ Another possible differentiator of social investors is a willingness to accept risks that other investors do not, with less of a financial risk premium than non-social investors. Social investors may also be willing to subsidize social businesses by willingly accepting a smaller financial return. Beyond profit, risk or return measures, social investors may take an active role in businesses they invest

\footnotetext{
investment (impact investment) as "Investments made into companies, organizations, and funds with the intention to generate social and environmental impact alongside a financial return." (From the Global Impact Investing Network website. https://thegiin.org/impact-investing/need-to-know/\#what-is-impact-investing. Accessed August 27, 2018.)

6 Unilever, Sustainable Living Report Hub. https://www.unilever.com/sustainable-living/our-sustainable-livingreport-hub/ Accessed August 28, 2018.

7 Unilever, “Our Brands." https://www.unilever.com/ Accessed August 28, 2018. See also https://www.unilever.com/ sustainable-living/enhancing-livelihoods/inclusive-business/creating-and-sharing-wealth/

8 We note that, in the age of what has been called "the second Internet boom," patience and the willingness to endure losses would not, in themselves, distinguish a social investor from many of the investors in Amazon, Facebook or Twitter. Indeed, there is an argument that patience on the part of investors in "platform" companies enables the social ill of building anti-competitive monopolies.
} 
in, for instance by taking positions on boards of directors, helping to solidify a business' commitment to social impact.

In these ways, implicitly and explicitly, financial trade-offs almost always lurk behind social investment. In our view, the willingness to accept a financial trade-off is what makes social investment distinct. However, how exactly to define these trade-offs, and the contours that distinguish between social investors-between actively and passively pursuing social good-requires much more thought and rigor. Students of philosophy, politics, and economics can sharpen these concepts. Useful starting points include Buffett and Eimicke (2018), who consider the role of philanthropy in "blended capital," and Cornée et al. (2018), who describe the optimal landscape of social business and investment, characterizing a range of institutions, some of which are unsubsidized and some of which take advantage of subsidized resources.

\section{Are prices too high?}

Tensions between financial and social goals run through the history of microfinance (Morduch 2000). The initial problem that Mohammed Yunus and other pioneers (including much earlier ones such as Jonathan Swift; Roodman 2012) sought to address was failures in credit markets. Economists had rooted those failures in information asymmetries so extreme that lenders found themselves unable to cover their costs (for example, Stiglitz and Weiss 1981; Armendáriz and Morduch 2010; Banerjee 2013). Microfinance contracts offered a possible solution to the information asymmetries, and subsidy (via social investment) also meant that earnings would not have to fully cover costs (for example, Conning and Morduch 2011; Ogden 2016). This need for a balance between financial constraints (that is, breaking even while generating a reasonable surplus) and community/social goals has also been central to the historical development of financial cooperatives, credit unions, and other cooperative organizations (Hansmann 1996; Armendáriz and Morduch 2010, chapter 3; Cornée et al. 2018).

Success for microfinance followed from a tilt toward financial goals, expressed in the argument that interest rates charged on loans to poor borrowers should be high enough that lenders could earn profit (Rosenberg 2002; Helms 2006). Raising interest rates was seen as the only way to create financial institutions that could grow and expand (Otero and Rhyne 1994). It was feared that the alternative would be even worse for under-served communities: fewer institutions serving the poor. Vikram Akula, the founder of India's SKS, for example, celebrated the rapid expansion of SKS and his "unexpected quest to end poverty through profitability" (Akula 2011).

While some microfinance interest rates have pushed beyond 100 percent per year, notably at the Mexican lender Compartamos at the time of its IPO (Rosenberg 2007), most inflation-adjusted microfinance interest rates are far lower, around 20-40 percent per year (Cull et al. 2009), which is neither cheap nor outrageously 
high. Still, one of the notable facts about microfinance is that poorer customers tend to be more costly to serve (per unit transacted) than richer customers. As a result, they also usually pay more (Cull et al. 2009). By the logic of social business, customers of institutions serving poorer customers thus tend to be charged much higher interest rates than customers of institutions serving richer customers. While this may be the opposite of what is expected for a "social" business, it is very much in line with the ethos of the commercial wing of microfinance.

Not surprisingly, scholars raise ethical problems (Hudon and Sandberg 2013), some arguing vigorously that, rather than helping the poor, microfinance interest rates are part of a system that undermines the poor, leading to cycles of debt (for example, Bateman 2010; Karim 2011; Bateman and Chang 2012; Guérin et al. 2015). Even long-time advocates for microfinance worry. Richard Rosenberg (2009), for example, disparaged the "New Moneylenders" in a publication of the Consultative Group to Assist the Poor, a middle-of-the-road donor group. More publicly, Muhammad Yunus (2011: A23) railed against the financial strategies of Compartamos and SKS in the opinion pages of the New York Times:

Commercialization has been a terrible wrong turn for microfinance, and it indicates a worrying "mission drift" in the motivation of those lending to the poor. Poverty should be eradicated, not seen as a money-making opportunity.

The unresolved questions suggest a multi-pronged research agenda, including at least three separate inquiries.

The first is ethical. How should the gains of some customers be weighed against the harms of other customers? Specifically, how should access by some communities at cheap prices (an approach with low interest rates that might not fully cover costs) weigh against the possibility of wider access by others but at higher (commerciallyviable) prices? Does it matter that engagement with microfinance is purely voluntary, at least on the surface? What is the nature of choice and consent in signing contracts? Starting points include Hudon and Sandberg (2013), Hulme and Maitrot (2014), and Hudon et al. (2018).

Addressing ethical concerns in practice often involves consumer protections, either self-imposed by institutions or imposed by external regulators. The SMART campaign (www.smartcampaign.org), for example, is an industry-led effort to self-regulate "responsible pricing", fair treatment of customers, and avoiding overindebtedness, among other concerns. Schicks (2013), for another example, uses a "customer protection" framework to bring attention to over-indebtedness. But how well does self-regulation work? What are the advantages and disadvantages of external regulation? To what extent do (populist) political agendas clash with some commercial imperatives of microfinance institutions? Or, as Hansmann (1996) describes in a historical view of the development of commercial insurance, to what extent are commercial possibilities and consumer protection in fact complementary? 
A second line of inquiry involves interest rate caps. The political victory won by microfinance advocates hinged on revealing the unintended consequences of interest rate caps. Experience had shown that regulations that kept interest rates too low often encouraged corruption and inefficiency (Armendáriz and Morduch 2010), especially in state-run banks that were already subject to political influence. A recent example (focused on state-run banks but not microfinance specifically) is described by Bircan and Saka (2018) in Turkey. Using data on all loans since 2003, they show that state-owned banks systematically adjusted their lending in ways that supported the ruling party (especially at the time of local elections), diverting funds from other creditworthy recipients. A starting point is to derive theoretically-consistent optimal levels of interest rate caps that balance efficiency and equity concerns. Then, as an empirical question, determine how far are existing microfinance interest rates from those optimal levels.

A third line of inquiry involves customer responsiveness to and customer welfare effects of the cost of credit. Early on, it was asserted that customers tend to be insensitive to interest rates, thus justifying their increase. But the claim had neither clear logical nor empirical backing (Morduch 2000). Subsequent studies have shown that customers can be highly sensitive to interest rate changes (for example, Dehejia et al., 2012, in urban Bangladesh and Karlan and Zinman, forthcoming, in Mexico).

As with any loan, the cost is not just the interest rate. Recent work in the United States shows that borrowers financing an automobile are willing to pay higher interest rates over a longer term, and pay a higher price, in exchange for a smaller monthly payment (Argyle et al. 2018). For customers with binding liquidity and credit constraints it's not obvious how much such a shift in terms is welfarereducing or enhancing. It's an important question as the microfinance industry adopts more asset-financing products such as loans for solar panels, sanitation, cook stoves and the like. (See also Bauchet and Morduch 2018 on payment modalities in microinsurance.)

Apart from expanding the range of studies of price responsiveness, priorities include: empirical studies that focus on who is most sensitive to prices; how price responsiveness differs between interest rate and term or other contract features; and how prices affect the well-being of customers and their composition (that is, how prices and terms function as screening devices for customers; see for example, Barboni and Agarwal 2018).

\section{Mission drift}

The tension between profit and social impact runs through the history of microfinance and is echoed in concerns about social business. The interest rate debates described above are central to this tension, as is a long-standing worry about mission drift. Will organizations that start with a balance weighted toward social 
impact drift over time toward activities_and customers-that are more profitable? Will they abandon their most under-served customers in order to generate profit?

In principle, mission drift should be easy to measure, and the question should thus be easy to resolve empirically_but it is not (Armendáriz and Szafarz 2011). Mission drift ultimately requires longitudinal household-level data on the socio-economic status of customers, but microfinance institutions do not typically collect that kind of data and, despite attempts to collect distributional data on customers, variables are still patchy in cross-institution data repositories (Bauchet and Morduch 2010). Researchers have thus turned to the proxies that institutions collect, most often average loan size. Average loan size is justified by the correlation of household income and the typical scale of borrowing: poorer customers tend to take smaller loans (Cull et al. 2009). Increases in average loan size over time are then taken as proxies for mission drift.

Using average loan size as a proxy as well as the fraction of female customers, Cull et al. (2007) find only moderate evidence of mission drift in a global cross-section of microfinance institutions (after controlling for institutional characteristics, including the institution's age, size, formal profit status, interest rates, region, and capital structure). The results show that some financially self-sustainable institutions manage to also serve a large share of women and poorer customers. At the same time, clear trade-offs emerged for larger and older institutions. Mersland and Strøm (2010) provide complementary analysis with an instrumental variables approach in a database from a credit rating organization, again finding only modest signs of mission drift.

But average loan size is far from a perfect proxy for mission drift. To see that, consider a simple scenario in which half of all borrowers from a particular lender take $\$ 100$ loans; the other half takes $\$ 500$ loans. The average loan size is then $\$ 300$. If the borrowers do well and each wants to increase their loan sizes by $\$ 100$ in the next year of borrowing, the average loan size jumps to \$400. Is that mission drift? Most would say that the lender is simply meeting the needs of its successful customers-after all, the customers have not changed, only their needs have. Or consider a case in which the lender expands their operations to serve richer customers who demand bigger loans-but continues to serve their poorer customers with the same commitment as before. That too would appear as mission drift as measured by average loan size, even though poor customers have not been abandoned. Collecting and analyzing reliable data which can show mission drift (or lack of mission drift) in detailed customer-level data would be valuable.

The mechanisms behind mission drift also matter. Copestake (2007), for example, focuses on the role of social performance management as a way to mitigate drift. Biancini et al. (2017) turn to micro theory to argue that mission drift can occur if institutions lack the incentives to make costly investments required to identify the potentially-valuable projects of poorer customers and to monitor effort. Conning and Morduch (2011) investigate similar tensions, also in the context of asymmetric 
information between lenders and borrowers. Beisland et al. (2017) find evidence that loan officers make investments to identify poorer borrowers, but they make fewer loans to these riskier customers over time. Hossain and Mullally (2018) find similar evidence in Bangladesh. Using a randomized controlled trial, Giné et al. (2018) show a role for performance bonuses given to workers in a mission-oriented nonprofit; when the workers are given extra compensation for success on financial metrics, those metrics improve but at the expense of social outcomes.

Microfinance offers a laboratory to understand these mechanisms, and the frameworks of Biancini et al. (2017) and Conning and Morduch (2011) translate easily to broader examples of social business. A broader theoretical framework which pulls in social motivation on the part of workers is reviewed by Besley and Ghatak (2018). These within-institution mechanisms are an area ready for much more research.

\section{What is the role of subsidy?}

The sections above describe tensions and trade-offs that run through social business and social investment, despite the early hope that profitability and social impact can go hand-in-hand without trade-off. The data presented in microfinance industry databases suggests, on the surface, that the trade-offs between profit and social impact are small (MIX Market 2015). But Cull et al. (2018) gained access to the underlying data from the MIX Market database to investigate the underpinnings of the microfinance business model. They analyze data on 1,335 institutions to show that larger trade-offs emerge under realistic economic assumptions. They show that while the MIX Market data suggest that just over half of institutions were profitable, further adjustments reduce the figure to just 36 percent. In one form or another, most institutions relied on subsidy. (For related analysis and discussion, see, for example, D'Espallier et al. 2017; Hartarska and Nadolnyak 2007; Hermes and Lensink 2011; Hermes et al. 2011; Hudon and Traca 2011.)

Cull et al. (2018) extend methods developed by Yaron (1994) and Schreiner and Yaron (2001). The methods account for implicit subsidy by using a more realistic value for the opportunity cost of capital than is generally the practice. While this is a step forward, it remains a very static endeavor. For example, Cull et al. (2018) find that older institutions account for a large share of the subsidy. Of the total subsidy they measured, three-quarters went to the 932 institutions in their sample that were older than ten years. The finding is striking given that industry experts have seen subsidy as a start-up support which will disappear over time. Those older institutions should thus be nearly subsidy-free. But, in fact, because many of the older institutions have continued to expand into new areas, they are both old (in years since their founding) and new (in the sense of continuing to build new branches). Only with disaggregated data, can further progress be made, perhaps with detailed financial case studies from particular institutions. 
A case study approach might also help address a different dynamic issue: institutions may be subsidized simply because subsidized social investment is available. (In contrast to the assumption that subsidized social investment is a response to the needs of unprofitable social businesses.) The institutions might be foolish to turn their backs on this cheap capital, and this does not necessarily make them "subsidy dependent" in the sense of Yaron (1994). The (dynamic) question is whether the institutions are able to re-optimize adequately well if access to subsidy is curtailed.

\section{Measuring social returns}

The one question we hear more than any other is: How should social investors measure social returns? By this, social investors mean, how can we create a measure of social impact that is comparable to measures of financial performance? They want to know, for example, that this $\$ 1000$ investment saved this many lives or raised this many math scores or reduced this much disease. It is a fair question, and it aligns with a commitment of the Global Impact Investing Network to measurement: "A hallmark of impact investing is the commitment of the investor to measure and report the social and environmental performance and progress of underlying investments, ensuring transparency and accountability while informing the practice of impact investing and building the field." ${ }^{\prime 9}$

Yet the answer is elusive. Social impact is properly understood as the net difference between a change due to an intervention versus what would have happened without the intervention. Social scientists use the "potential outcomes" framework to clarify what is meant by causal impacts (Rubin 2005). Applied here, impact is defined as the difference between outcomes with "exposure" to the products or services of the social business versus a counterfactual scenario in which all else is the same but there is no such exposure. Some call this additionality, but while the Rubin (2005) model is precise, applications are generally loose. (See Carter et al., 2018 , for a discussion of the hurdles in measuring additionality.)

The framework shows that it is not enough to know that a company sold solar panels, say. It is also necessary to know how the solar panels affected people's lives. For example, did children learn more because they were able to study at night? More difficult, it is also necessary to estimate what would have happened without the solar panels-which then needs to be netted out to form the estimate of (net) impact. The need for a counterfactual usually requires comparisons to a control group, and the credibility of the measurement depends fundamentally on the appropriateness of the control group (see the discussion in Ogden 2017 of ways that randomized control trials (RCTs) are being used). Yet in much social investment, there are no obvious control groups, and little apparent willingness on the part of social investors to pay the costs necessary for social businesses to credibly

9 Global Impact Investing Network website. https://hegiin.org/impact-investing/need-to-know/\#core-characteris tics-of-impact-investing. Accessed August 27, 2018. 
measure impact (which would, after all, belie the "no trade-offs" rhetoric). There thus remains a large gap between the way that social investment is described and what is possible to execute in practice.

Illustrating that measuring impact is crucial, Lee et al. (2018) investigate rural electrification and "do not find meaningful medium-run impacts on economic, health, and educational outcomes, nor evidence of spillovers to unconnected local households." Similarly, Wydick et al. (2016) find that distributing free shoes to children causes them to do less homework (because they spend more time outside playing).

Here, we focus on an under-studied aspect of measuring social returns, comparing the impacts to costs. ${ }^{10}$ The question about the social returns to social investment is not just one about impact measurement. The social impact of microfinance has been evaluated over the years, most recently with randomized controlled trials. ${ }^{11}$ But the discussion does not stop with measured impact. Measuring social returns also entails a comparison of measured impact to measured costs in order to estimate the change due to a given financial investment. The benefit-cost comparison can dramatically change the picture. Cull et al. (2018), for example, show that while some measured impacts of microfinance seem modest (for example, Banerjee et al. 2015), the costs are also relatively low compared to similar interventions. As a consequence, benefit-cost ratios can look appealing. In fact, they look better than some much-discussed grant-based interventions.

The benefit-cost ratios in Cull et al. (2018) are simplified through plausible assumptions, but they are still back-of-the envelope calculations. One important line of inquiry is thus to figure out how to form rigorous benefit-cost comparisons. In doing so, challenges will emerge on the cost side as well as the benefit side. For example, microfinance evaluations, especially those using RCTs, generally only yield measures of marginal impact (for a new region or population), not average impact on all borrowers (Banerjee et al. 2015). Yet, financial data on costs are often averages for the entire institution. Generating reliable benefit-cost estimates will hinge on matching the nature of the impact estimate (marginal vs average) and the nature of the cost data. A detailed case study seems like the natural path to begin working this out. McIntosh and Zeitlin (2018) lay the groundwork with a detailed attempt to account for costs to benchmark a water and sanitation intervention against the alternative of simply giving cash.

We close this section with a broader, conceptual thought. Not everyone who has the chance to buy a solar panel will buy one. Not everyone offered a loan will take one. Not everyone with access to a savings account will use it. Yet when impact is

\footnotetext{
10 For a discussion of how to measure benefits, see Chapter 5 in this volume by Bert D'Espallier and Jann Goedecke ("Social performance measurement in microfinance").

11 For a critical discussion and review of recent studies, see Cull and Morduch 2018. For insights from leading scholars using randomized methods, see Ogden 2017.
} 
measured, it only reflects the impact created by the subset of the population that bought the panel, took the loan, or saved in the account. Still, there may be a value in simply knowing that you can now buy a solar panel if you want (even though you have not yet), or that you could take a loan or start saving in your account. Amartya Sen captures this idea through the idea of "capabilities" (valuing the capacity to act, whether or not one actually acts). To the extent that it is capabilities that really matter, it is not clear how to incorporate them when measuring social returns-but creating capabilities is the most fundamental benefit for communities served by social business (Hudon and Sandberg 2013). If efforts to use distributing unconditional cash as a benchmark for other impact and cost-benefit comparisons catch on, as per Blattman and Niehaus (2017) and McIntosh and Zeitlin (2018), this question will become all the more vital-and challenging-for social investors to answer. What is the value of the capability to buy a solar panel compared to the ability to buy anything one wishes with an equivalent amount of cash?

\section{A final thought}

The early decades of the microfinance movement were carried forward by enthusiasm about new possibilities. Relatively little progress was made on the hard questions on the research agenda, those concerning economic trade-offs and measuring net impacts (Morduch 2017). Today, the hard microfinance questions are finally being asked and some are being answered, with findings that are sometimes inspiring and sometimes disappointing. The broader social investment sector is mostly where microfinance used to be-the enthusiasm and momentum have left too many hard questions insufficiently answered. Now, though, the microfinance sector can be a leader rather than a laggard in posing and answering hard questions, providing a framework and benchmarks to extend and challenge social investment.

\section{References}

Akula, V. (ed.) (2011), A Fistful of Rice: My Unexpected Quest to End Poverty Through Profitability, Boston, MA: Harvard Business Review Press.

Argyle, B., T. Nadauld, C. Palmer and R. Pratt (2018), 'The capitalization of consumer financing into durable goods prices', NBER Working Paper No. 24699.

Armendáriz, B. and J. Morduch (eds.) (2010), The Economics of Microfinance, Second edition, Cambridge, MA: MIT Press.

Armendáriz, B. and A. Szafarz (2011), 'On mission drift in microfinance institutions', in B. Armendáriz and M. Labie (eds.), The Handbook of Microfinance, Singapore: World Scientific Publishing.

Banerjee, A. (2013), 'Microcredit under the microscope: what have we learned in the past two decades, and what do we need to know?', Annual Review of Economics, 5(1), 487-519.

Banerjee, A., D. Karlan and J. Zinman (2015), 'Six randomized evaluations of microcredit: introduction and further steps', American Economic Journal: Applied Economics, 7(1), 1-21.

Barboni, G. and P. Agarwal (2018), 'Knowing what's good for you: can a repayment flexibility option in microfinance contracts improve repayment rates and business outcomes?', Working Paper, http:// www.giorgiabarboni.com/home/Research_files/Barboni_JMP.pdf 
Bateman, M. (ed.) (2010), Why Doesn't Microfinance Work? The Destructive Rise of Local Neoliberalism, London: Zed Books.

Bateman, M. and H.-J. Chang (2012), 'Microfinance and the illusion of development: from hubris to nemesis in thirty years', World Economic Review, 1, 13-36.

Bauchet, J. and J. Morduch (2010), 'Selective knowledge: reporting bias in microfinance data', Perspectives on Global Development and Technology, 9 (3-4), 240-269.

Bauchet, J. and J. Morduch (2018), 'Paying in pieces: a natural experiment on consumer demand under different payment schemes', Purdue University and New York University, Working Paper.

Beck, T. (2015), 'Microfinance-a critical literature survey', World Bank Independent Evaluation Group, IEG Working Paper 2015/4.

Beisland, L., B. D'Espallier and R. Mersland (2017), 'The commercialization of the microfinance industry: is there "personal mission drift" among credit officers?', Journal of Business Ethics, 1-16. https:// doi.org/10.1007/s10551-017-3710-4

Besley, T. and M. Ghatak (2018), 'Pro-social motivation and incentives', Annual Review of Economics, 10, $411-438$.

Biancini, S., D. Ettinger and B. Venet (2017), 'Mission drift in microcredit and microfinance institution incentives', CESifo Working Paper Series 6332, CESifo Group Munich.

Bircan, Ç. and O. Saka (2018), 'Political lending cycles and real outcomes: evidence from Turkey', EBRD and LSE Working Paper.

Blattman, C. and P. Niehaus (2014), 'Show them the money: why giving cash helps alleviate poverty', Foreign Affairs, May/June 2014. https://www.foreignaffairs.com/articles/show-them-money.

Buffett, H. and W. Eimicke (eds.) (2018), Social Value Investing: A Management Framework for Effective Partnerships, New York: Columbia University Press.

Bugg-Levine, A. and J. Emerson (eds.) (2011), Impact Investing: Transforming how we make money while making a difference, San Francisco, CA: Jossey-Bass.

Carter, P., N. Van de Sijpe and R. Calal (2018), 'The elusive quest for additionality', Center for Global Development working paper 495, Washington, DC, September.

Conning, J. and J. Morduch (2011), 'Microfinance and social investment', Annual Review of Financial Economics, 3(1), 407-434.

Copestake, J. (2007), 'Mainstreaming microfinance: social performance management or mission drift?', World Development, 35(10), 1721-1738.

Cornée, S., M. Jegers and A. Szafarz (2018), 'A theory of social finance', Centre Emile Bernheim Working Paper No. 18/010, February.

Cull, R. and J. Morduch (2018), 'Microfinance and development', in Thorsten B. and R. Levine (eds.), The Handbook of Finance and Development, Cheltenham, UK and Northampton, MA, USA: Edward Elgar Publishing.

Cull, R., A. Demirgüç-Kunt and J. Morduch (2007), 'Financial performance and outreach: a global analysis of leading microbank', Economic Journal, 117(517), F107-F133.

Cull, R., A. Demirgüç-Kunt and J. Morduch (2009), 'Microfinance meets the market', Journal of Economic Perspectives, 23(1), Winter, 167-192.

Cull, R., A. Demirgüç-Kunt and J. Morduch (2018), 'The microfinance business model: enduring subsidy and modest profit', World Bank Economic Review, 32(2), 221-244.

D'Espallier, B., J. Goedecke, M. Hudon and R. Mersland (2017), 'From NGOs to banks: does institutional transformation alter the business model of microfinance institutions?', World Development, 89, 19-33.

Dehejia, R., H. Montgomery and J. Morduch (2012), 'Do interest rates matter? Credit demand in the Dhaka slums', Journal of Development Economics, 47(2), 437-499.

Elkington, J. (2018), '25 years ago I coined the phrase “triple bottom line.” Here's why it's time to rethink it', Harvard Business Review (online), June 2 https://hbr.org/2018/o6/25-years-ago-i-coined-the-phrase -triple-bottom-line-heres-why-im-giving-up-on-it 
Giné, X., G. Mansuri and Slesh A. Shrestha (2018), 'Mission and the bottom line: performance incentives in a multi-goal organization', World Bank, May.

Giridharadas, A. (ed.) (2018), Winners Take All: The Elite Charade of Changing the World, New York: Brozoi/Knopf.

Gold, J. (2017), 'A standard ESG framework is key to unleashing markets' responsible growth', S\&P Global (online). 17 June.

Guérin, I., M. Labie and J.-M. Servet (eds.) (2015), The Crises of Microcredit, London: Zed Books.

Hansmann H. (ed.) (1996), The Ownership of Enterprise, Cambridge, MA and London: Harvard University Press, Belknap Press.

Hartarska, V. and D. Nadolnyak (2007), 'Do regulated microfinance institutions achieve better sustainability and outreach?', Applied Economics, 39, 1207-1222.

Helms, B. (ed.) (2006), Access for All: Building Inclusive Financial Systems (An Excerpt), Washington, DC: CGAP.

Hermes, N. and R. Lensink (2011), 'Microfinance: its impact, outreach, and sustainability', World Development, 39(6), 875-881.

Hermes, N., R. Lensink and A. Meesters (2011), 'Outreach and efficiency of microfinance institutions', World Development, 39(6), 938-948.

Hossain, M. and C. Mullally (2018), 'Asset transfer leading to microcredit: encouragement, selection and outcomes', University of Florida, Working Paper. https://www.dropbox.com/s/w7vmwyiyzixexk2/ BD\%2ocredit\%2opaper_Hossain.pdf?dl=o

Hudon, M. and D. Traca (2011), 'On the efficiency of subsidies in microfinance: an empirical inquiry', World Development, 39(6), 966-973.

Hudon, M. and J. Sandberg (2013), 'The ethical crisis in microfinance: issues, findings, and implications', Business Ethics Quarterly, 23(4), 561-589.

Hudon, M., M. Labie and P. Reichert (2018), 'What is a fair profit for social enterprise? Insights from microfinance', Journal of Business Ethics, 1-18. https://doi.org/10.1007/s10551-018-3986-z

Hulme, D. and M. Maitrot (2014), 'Has microfinance lost its moral compass?' Economic and Political Weekly, 49(48), November, 77-85.

Karim, L. (ed.) (2011), Microfinance and Its Discontents: Women in Debt in Bangladesh, Minneapolis, MN: University of Minnesota Press.

Karlan, D. and J. Zinman (forthcoming), 'Long-run price elasticities of demand for credit: evidence from a countrywide field experiment in Mexico', Review of Economic Studies.

Lee, K., E. Miguel and C. Wolfram (2018), 'Experimental evidence on the economics of rural electrification', University of Chicago and University of California, Berkeley, Working Paper.

McIntosh, C. and A. Zeitlin (2018), 'Benchmarking a child nutrition program against cash: experimental evidence from Rwanda', Working Paper, https://www.poverty-action.org/publication/bench marking-child-nutrition-program-against-cash-experimental-evidence-rwanda

Mersland, R. and R. Øystein Strøm (2010), 'Microfinance mission drift?', World Development, 38(1), 28-36.

MIX Market (2015), Global Outreach E Financial Performance Benchmark Report - 2015, Washington, DC: The MIX Market.

Morduch, J. (2000), 'The microfinance schism', World Development, 28(4) (April), 617-629.

Morduch, J. (2017), 'Microfinance as a credit card?', in Stephen J. Collier, Jamie Cross, Peter Redfield and Alice Street (eds.), Limn, Issue 9: Little Development Devices/Humanitarian Goods.

Ogden, T. (2016), The Case for Social Investment in Microcredit, New York: Financial Access Initiative.

Ogden, T. (ed.) (2017), Experimental Conversations: Perspectives on Randomized Trials in Development Economics, Cambridge, MA: MIT Press.

Otero, M. and E. Rhyne (eds.) (1994), The New World of Microenterprise Finance: Building health financial institutions for the poor, Kumarian Press. 
Roodman, D. (2012), Due Diligence: An Impertinent Inquiry into Microfinance, Baltimore, MD: Brookings Institution Press.

Rosenberg, R. (2002), 'Microcredit interest rates', CGAP Occasional Paper.

Rosenberg, R. (2007), 'CGAP reflections on the Compartamos initial public offering: a case study on microfinance interest rates and profits', CGAP Focus Note No. 42, June.

Rosenberg, R. (2009), 'The new moneylenders: are the poor being exploited by high microcredit interest rates?', CGAP Occasional Paper 15, Washington, DC: Consultative Group to Assist the Poor.

Rubin, D. (2005), 'Causal inference using potential outcomes', Journal of the American Statistical Association, 100(469), 322-331.

Schicks, J. (2013), 'The definition and causes of microfinance over-indebtedness: a customer protection point of view', Oxford Development Studies, 41, S95-S116.

Schreiner, M. and J. Yaron (eds.) (2001), Development Finance Institutions: Measuring their Subsidy, Washington, DC: The World Bank.

Simon, M. (ed.) (2017), Real Impact: The New Economics of Social Change, New York: Nation Books.

Spiess-Knafl, W. and B. Scheck (eds.) (2017), Impact Investing: Instruments, Mechanisms and Actors, Palgrave Macmillan.

Sindreau, J. and S. Kent (2018), 'Why it's so hard to be an "ethical" investor', Wall Street Journal, September 1.

Stiglitz, J. and A. Weiss (1981), 'Credit rationing in markets with imperfect information', American Economic Review, 71, 393-410.

Taitel, S. (2018), 'MISSION framework: market-based solutions for social impact', Blog post, Michael and Susan Dell Foundation. May 2, 2018. https://www.msdf.org/blog/2018/o5/ market-based-solutions-for-social-impact/

Wydick, B., Elizabeth Katz, Flor Calvo, Felipe Gutierrez and Brendan Janet (2016), 'Shoeing the children: the impact of the TOMS shoe donation program in rural El Salvador', The World Bank Economic Review 32(3), 727-751. https://doi.org/10.1093/wber/lhw042

Yaron, J. (1994), 'What makes rural finance institutions successful?', World Bank Research Observer, 9(1), January.

Yunus, M. (2010), Building Social Business: The New Kind of Capitalism that Serves Humanity's Most Pressing Needs, New York: Public Affairs.

Yunus, M. (2011), 'Sacrificing microcredit for megaprofits', New York Times, January 15, 2011. https:// www.nytimes.com/2011/01/15/opinion/15yunus.html

Yunus, M. (2017), A World of Three Zeroes: The New Economics of Zero Poverty, Zero Unemployment, and Zero Net Carbon Emissions, New York: Public Affairs. 